\title{
Asbestos Exposure and Lung Carcinogenesis: Mechanism and Applications
}

\author{
Pervin Elvan Tokgun \\ Pamukkale University, Faculty of Medicine, Department of Medical Genetics, Denizli, Turkey \\ E-mail: elvanars@gmail.com / parslan@pau.edu.tr \\ Ayse Gaye Tomatir (Corresponding author) \\ Pamukkale University, Faculty of Medicine, Department of Medical Biology, Denizli, Turkey \\ E-mail: tomatir@pau.edu.tr / tomatir64@gmail.com
}

\begin{abstract}
Use of asbestos was very common in industries for manufacturing, mining, and construction Silicates have 2 types including amphibole and serpentine fibers according to their morphology. The amphiboles are rigid, straight, needlelike fibers where crocidolite, amosite, tremolite, actinolite and anthophyllite are the major types Chrysotile is the only type with a commercial importance today which has curly, pliable fibers.5 Exposure to asbestos dust can occur via two major sources either with the primary occupations as a result of asbestos processing and mining or secondary occupations like shipbuilding, construction, manufacturing (textile, insulation, gaskets).

Asbestos is an important public health problem which is associated with severe diseases, such as mesothelioma, lung cancer and fibrosis. Although it has been banned in several countries, some are still producing or using. Asbestos exposure has shown to have broad effects on regulatory pathways.

The incidence of the related diseases are increasing in the recent years. Due to the very limited efficacy of the therapies, prognosis is unfortunately quite poor. To improve early detection and diagnosis, new approaches are being required. Although some of clinical prognostic factors have been identified up to date, novel biomarkers should be taken in consideration to predict its malignancy.
\end{abstract}

Keywords: Asbestos, Asbestos Exposure, Lung Carcinogenesis.

DOI: $10.7176 / \mathrm{JSTR} / 5-6-02$

\section{Introduction}

Use of asbestos was very common in industries for manufacturing, mining, and construction ${ }^{1-3}$ Silicates have 2 types including amphibole and serpentine fibers according to their morphology. The amphiboles are rigid, straight, needlelike fibers where crocidolite, amosite, tremolite, actinolite and anthophyllite are the major types (Figure 1). ${ }^{4}$ Amphiboles accounts for only $10 \%$ of the asbestos while serpentine is the rest 90\%. The major types of serpentine fibers are: Chrysotile, Lizardite and Antigorite (Figure 1). Chrysotile is the only type with a commercial importance today which has curly, pliable fibers. ${ }^{5}$ Exposure to asbestos dust can occur via two major sources either with the primary occupations as a result of asbestos processing and mining or secondary occupations like shipbuilding, construction, manufacturing (textile, insulation, gaskets). ${ }^{3}$

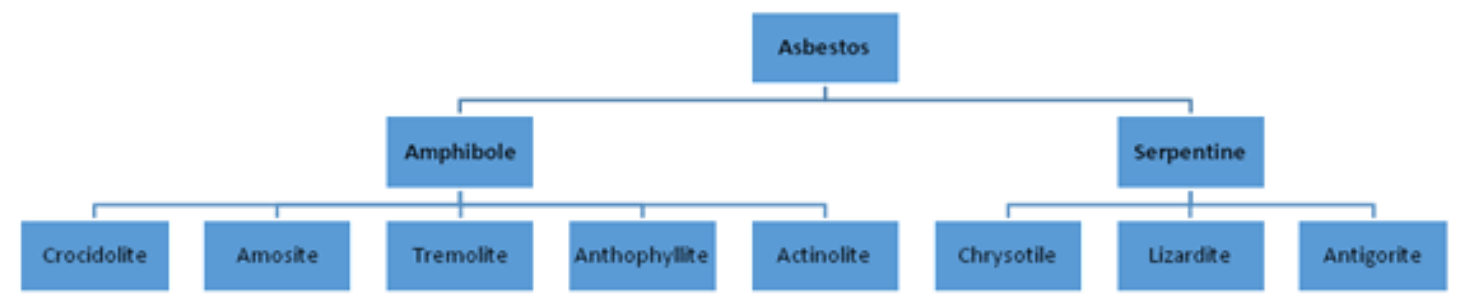

Figure 1. Asbestos fibers classification. 
It is hypothesized that cancer development risk from asbestos exposure could be depending on fibre size, but there are limited epidemiological data because approaches generally used to measure asbestos concentrations remain incapable of determining the size distributions of all airborne fibres. Size of asbest fibers are variable. ${ }^{6}$ Only fibres longer than $5 \mu \mathrm{m}$, less than about $0.25 \mu \mathrm{m}$ in diameter and width aspect ratios $\geq 3$ are usually excluded. The majority of airborne fibres in several industries are shorter than 5 $\mu \mathrm{m} .{ }^{7}$ Asbest pathogenity is effected by the fiber diameter and length, exposure-dose and time. ${ }^{8}$ Fibres with fiber diameter less than 0.25 micron and length $\geq 8$ micron are found to be more effective in tumourigenesis. ${ }^{9,10}$

All kinds of asbest are carcinogenic. Previous studies showed that the most carcinogenic type is crocidolite which causes malign mesothelium. ${ }^{11}$ Even the effect of crocidolite is 2-4 times more stronger than chrysotile all kinds of asbest have the capability of causing lung cancer. ${ }^{12-14}$

Asbestos related pleuro-pulmonare diseases are; Diffuse Pleural plaques, Benign Asbest Pleuritis, Malign Pleural Mesothelium, Lung Carsinoma and Asbestosis. ${ }^{15,16}$ Pleural effusions are generally seen in the first 10-20 years and the most common abnormality occured as a result of asbestos exposure. Pleural effusions may occur even after exposing minimal doses of asbestos. These effusions can be benign or malignant form and sometimes a large pleural effusion can be the first indicator of a pleural mesothelioma. Another indicator of asbestos exposure is pleural plaques, which generally occur more than 20 years later but their pathogenesis remains uncertain. ${ }^{3,17,18}$

Multiple benign asbestos-related pleural effusions induce diffuse pleural thickening. Based on the studies, it is believed that the progress of diffuse pleural thickening is related to the asbestos exposure, not like to pleural plaques. ${ }^{17,18}$ Asbestosis is defined as lung bilateral diffuse interstitial fibrosis caused by inhalation of asbestos fibers. ${ }^{19}$

Malignant pleural mesothelioma (MPM) is described as the most common pleural primary neoplasm ${ }^{5}$ which have three histologic types including ephitelioid (50-70\%), sarcomatoid (10-20\%) and biphasic $(25-35 \%) .^{20}$

\section{Genomic Alterations As a Result of Asbestos Exposure}

Asbestos fibers have ability to promote various chromosomal aberrations including aneuploidy, micronucleus formation, ${ }^{21,22}$ and DNA strand breaks which were reported to be deactivated by antioxidants, iron chelators or free radical scavengers underlining the importance of oxidative stress in genotoxicity induced by asbestos exposure..$^{23,24,25}$

Asbestos causes pleural disease, progressive pulmonary fibrosis and malignancies such as malignant mesothelioma and bronchogenic carcinoma. Asbestos related diseases occur after 15-40 years. The action mechanisms underlying mesothelioma, asbestosis and lung cancer are assumed to be different depending on the type of the fiber, lung clearance, and genetics. Asbestos can promote protein expression, gene transcription and DNA damage responsible for altering proliferation, inflammation and cell death. Molecular targets of asbestos include important biological macromolecules like DNA, signal transduction proteins and lipid membranes (Figure 2). The main signalling pathways affected by asbestos exposure include those involved in DNA repair, inflammation, mitochondrial activity, oxidative stress and apoptosis.

A rare type of cancer, MPM, is originated from pleural and peritoneal mesothelial cells. $85 \%$ of MPM cases have found to be relevant to long-term asbestos exposure. Genome-wide expression results showed significantly greater changes in pleural mesothelial cells. Above all, in pleural mesothelial cells IL-8, ATF3, CXCL2, CXCL3, IL-6, GOS2 found to have a greater response compared to peritoneal mesothelial cells. ${ }^{26}$

Numerous genomic alterations have been detected up to date in Malignant mesothelioma (MM) in which the most frequent was the existance of homozygous deletion of, p16INK4a and p14ARF. p16INK4a/p14ARF homozygous deletion which leads to the inactivation of pRB and p53 has been reported to arise at $50-70 \%$ of MM tissues and primary cells whereas $90 \%$ in stable MM cell lines. ${ }^{27}$ 


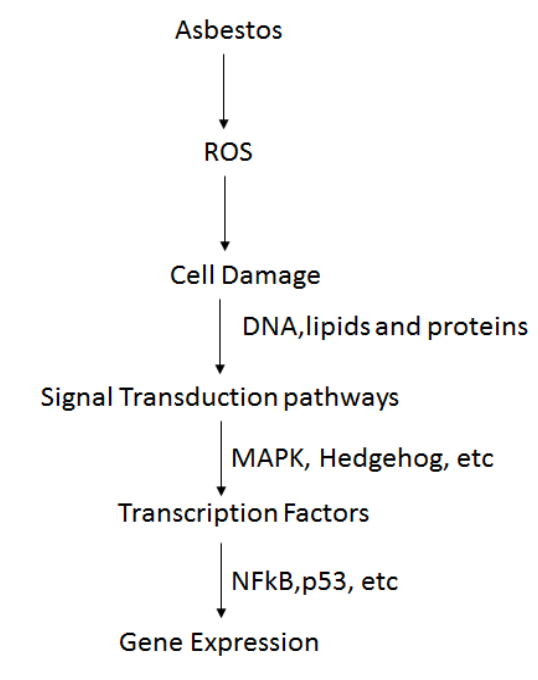

TNF- $\alpha$, TGF- $\beta$, p53, IL-1, IL-8, caspases, etc

Figure 2. Asbestos induced pulmonary toxicity mechanism.

\section{p53 pathway}

The transcription factor p53 regulates genes that have roles in cell cycle arrest, DNA repair, apoptosis, metabolism and senescence. It is called "guardian of genome" due to its role in protecting the genomic integrity of the cells under stressed conditions. p53 is shown to be mutated in about $50 \%$ of the human cancers. ${ }^{28}$ Although there is not so much information about how most of the tumor suppressor genes have a central role in the pathogenesis of pulmonary diseases induced by asbestos, there are increasing credential suggesting that changes in p53 function is important. Previous studies observed that in human lung carcinomas accumulation of p53 protein relates with asbestos directly but the correlation between p53 and mesotheliomas still remain not clear. ${ }^{29-31}$ In rats that exposed to aerosolised chrysotyle, increased expression of $\mathrm{p} 53$ protein was demonstrated at fibre deposition site. ${ }^{32}$

Many tumors as melanoma, colon carcinoma, Ewing's sarcoma and retinoblastoma exhibit overexpressed MDM2 which acts as primary negative regulator of the p53 and MDMX protein levels without increased copy number. ${ }^{33}$ MPM is a very aggressive tumor which might harbour wild-type p53. Preliminary studies suggested that MDM2 could be a potential target for anticancer treatment of MPM. ${ }^{34}$ And up to date only few studies focused on MDM2 in MPM.

\section{AKT pathway}

AKT is known to regulate the MDM2 localization in nucleus whereas MDM2 increases activation of AKT. ${ }^{35}$ The PI3K/AKT/mTOR pathway have a pivotal role in cancer development by regulating proteins incorporated in cell survival, cell proliferation, angiogenesis, tumor invasion, and metastasis. $65 \%$ of MPM tumors have shown to carry strong AKT activity right along with mTOR activation by Immunohistochemical analysis of phospho-AKT. Inhibition of AKT phosphorylation in MPM cells carrying elevated AKT activation has shown to affect cell survival and sensitivity to cisplatin treatment ${ }^{36}$ and abnormal activity of AKT appears to occur due to either the abnormal activation of Receptor Tyrosine Kinases (RTKs) ${ }^{37}$ and loss of PTEN, which is determined in more than $60 \%$ of MPMs. ${ }^{38}$ MDM2 which is a potential therapeutic target in mesothelioma, have been pointed for its antiapoptotic and promitogenic function. ${ }^{39}$

Chrysotile asbestos which is a commercial variety of serpentine fibres is related with high mortality from pulmonary diseases including asbestosis, mesothelioma, and lung cancer. Due to identification of various mechanisms underlying how chrysotile fibers promote pulmonary disease, the act of autophagy on epithelial cells remain unclear. Possible mechanisms on inducing autophagy are evaluated in A549 cells and reported that due to asbestos exposure expression levels of microtubule-associated protein 1 light chain 3 (LC3-II), dephosphorylated phospho-AKT, phospho-mTOR, and phospho-p70s6k were found to be increased. It was also demonstrated that an antioxidant, $\mathrm{N}$-acetylcysteine decreased chrysotile-induced dephosphorylation of $\mathrm{p}$-AKT and destroyed the phosphorylation/activation of c-Jun- $\mathrm{NH}_{2}$-terminal protein kinases. According to these findings, AKT/mTOR and JNK2 pathways are demonstrated to be essential for chrysotile-induced autophagy. By targeting those signalling pathways and understanding

11 | P a g e

www.iiste.org 
their underlying mechanisms it could be beneficial for possible future clinical applications in asbestosinduced lung disease. ${ }^{38}$

\section{Hedgehog Signalling}

The Hedgehog (Hh) signaling pathway is known to be inactive in most adult tissues but has been shown to become upregulated in MPM tumors ${ }^{40}$ and it appears that this pathway is located in the most deregulated pathway list in MPM. ${ }^{41}$

\section{MAPK pathway}

The activation of the MAPK pathway after exposure of asbestos have been shown in many studies. ERK1/2, JNK, and p38 kinases are the members of MAPK pathway. ERK1 and ERK2 which

are extracelular signal regulated kinases and JNK/p38 pathways could be important determinants of promoting apoptosis or cell survival. ${ }^{42,43}$ It is shown that phosphorylation and activation of ERK1 and ERK2 was proposed to be highly associated with cell proliferation which is responsible for MM development. ${ }^{26}$ ERK1 and ERK2 activation after exposuring to asbestos fibers have been shown in rodentmesothelial cells in vitro. ${ }^{44}$ Protein and phosphoprotein levels were examined to establish the interactive network between crocidolite-treated benign and malignant mesothelial cells and 21 differentially expressed proteins were identified where half were found to be involved in both EGFR/MAPK/ERK pathway and the PI3K/AKT pathways. Despite that c-Jun and ERK1/2 proteins were shown to be increased in previous studies which in one study it was found to be reduced. ${ }^{45}$ The activation and overexpression of RTKs has been related to asbestos resulting in MAPK pathway activation. ${ }^{27}$

\section{Hippo Signalling Pathway}

AP-1 and NF- $\kappa$ B can be triggered by the oxidative stress related to asbestos exposure. A Japanese group has been reported that in Merlin deficiency Hippo signaling pathway that is interacting with the TGF- $\beta$ pathway in order to operate the transcription of an important MM cell growth mediator, connective tissue growth factor (CTGF) via YAP-TEAD4-Smad3-p300 complex formation, is dysregulated. ${ }^{46,47}$

\section{Reactive Oxygene Species (ROS)}

Even though asbestos induces the production of ROS that cause pulmonary toxicity and DNA damage ${ }^{48-}$ ${ }^{51}$, Gang et al. ${ }^{52}$ focused on identifying the various mechanisms related to asbestos induced oxidative stress. Asbestos induced ROS production can occur from three sources including release from inflammatory cells, fiber surface reactivity and mitochondria derived ROS. Even though the pathogenesis of asbestosis is not very well understood, ROS may mediate the progression of the disease. ${ }^{53}$

ROS triggers NALP3 inflammasome activation, that is essential for mediating asbestos-induced inflammatory response. Besides it also mediates the activation of the NALP3 inflammasome partially through high mobility group box 1 (HMGB1), by contributing to asbestos-related inflammatory response with mature IL- $1 \beta$ secretion. ${ }^{54}$ Additionally, Fattman et al. ${ }^{53}$ have shown that EC-SOD depletion from the lung increase injury and oxidative stress in response to asbestos.

\section{Role of non-coding RNAs}

MicroRNAs (miRNA) are a part of a class of short non-coding RNAs that are approximately 18-22 nucleotides in length which involved in regulating gene expression at the post transcriptional level. ${ }^{55}$ It has been shown that approximately half of the known miRNAs are located in cancer-associated genomic regions or in fragile sites. ${ }^{56}$ They play a role as oncogenes/tumor suppressors. ${ }^{57-59}$ Studies have shown that miRNA profiling can differentiate tumor from normal cells, different tumor histological subtypes from each other and might potentially predict clinical outcome. ${ }^{59-61}$ miRNAs have multiple targets and can regulate groups of genes; thus, low-level modulation from individual miRNAs could have an additive effect on multiple gene targets. ${ }^{62}$ miRNAs have also played important roles in the development of MM as well as many other types of cancer. Up to now limited studies have utilized the deregulated expression of miRNAs for the diagnosis and treatment of MM. Gulet et al ${ }^{63}$ reported miRNAs that was differentially expressed between the neoplastic and unaffected tissue. Santarelli et al. ${ }^{64}$ highlighted the significance of miRNAs as early prediction tools of MM and they reported that miR-335, miR-126, and miR-32 were significantly down-regulated in the samples from ten freshly frozen MM biopsies whereas only miR-126 was validated to be downregulated in the malignant tissue.

Kirschner et al. ${ }^{65}$ evaluated 90 miRNAs in plasma/serum as diagnostic biomarkers for MM ${ }^{63-69}$ and identified the novel miR-625-3p by microarray analysis. The increased expression of miR-625-3p in plasma/serum have led to the assumption that it could be a promising novel diagnostic marker. ${ }^{65}$ It is

12 | P a g e

www.iiste.org 
speculated that the analysis of expression signatures for miRNAs and mRNAs in patients with MPM could differentiate benign pleural disease or metastatic cancer to the pleura from MPM, be useful for all of the histological subtypes of MPM in order to screen treatment response. Only a small number of studies have been done in MPM to examine miR expression ${ }^{63-72}$ and corresponding gene expression of these tumors we investigated the miRNA and mRNA expression levels and their integrated analysis in both benign asbestos-related pleural effusion and different stages and histological subtypes of MPM. There are multiple microRNAs discovered in malignant pleural mesothelioma such as hsa-miR-484, hsamiR-320, hsa-let-7a, and hsa-miR-125a-5p When compared to benign asbestos-related pleural effusion. These micRNAs were able to distinguish malignant from benign disease. As a result of miRNA-mRNA interactions analysis it is suggested there are multiple targets within the Notch signaling pathway. ${ }^{73}$ Latest studies revealed that miRNA-16 was directly related to prognosis of MPM patients and potential prognostic marker in MPM patients. ${ }^{74}$

By the data of the reports on detection of abnormal miRNA levels, a necessity has been arisen for analyzing the expression of a panel of miRNAs figured in MM development and progression.

Besides miRNAs also 13 lncRNAs in which Fendrr got the hightest levels are identified in mice mesothelioma and validated in patient samples suggesting that they contribute to human mesothelioma heterogeneity. ${ }^{75}$

\section{Conclusion}

Asbestos is an important public health problem which is associated with severe diseases, such as mesothelioma, lung cancer and fibrosis. Although it has been banned in several countries, some are still producing or using. Asbestos exposure has shown to have broad effects on regulatory pathways.

The incidence of the related diseases are increasing in the recent years. Due to the very limited efficacy of the therapies, prognosis is unfortunately quite poor. To improve early detection and diagnosis, new approaches are being required. Although some of clinical prognostic factors have been identified up to date, novel biomarkers should be taken in consideration to predict its malignancy.

\section{References}

1. Rom WN. Asbestos related lung disease. In: Fishman AP, Elias JA, Fishman JA, Grippi MA, Kaiser LR, Senior RM, ds. Fishman's Pulmonary Diseases and Disorders, 3rd Ed.,New York: Mc Graw Hill, 1998; 877-91.

2. Müller KM, Fischer M. Malignant pleural mesotheliomas: An enviromental health risk in southeast Turkey. Respiration 2000; 67(6): 608-9.

3. Peacock C, Copley SC, Hansell DM. Asbestos-related benign pleural disease. Clin Radiol 2000; 55(6):422-32

4. Atabey E. Türkiye'de Asbest, Eriyonit, Kuvars ve diğer mineral tozları ve etkileri (Asbestos, erionite, quartz and other mineral powders and their effect in Turkey). Maden tetkik ve arama genel müdürlüğü. Ares Basım Reklam Prodüksiyon Hizmetleri San.Tic. Ltd. Şti; Ankara. p;7, 2009.

5. Norbet C, Joseph A, Rossi SS, Bhalla S, Gutierez FR. Asbestos-Related Lung Disease: A Pictorial Review. Current problems in diagnostic radiology 2015; 44(4): 371-82.

6. Robledo R, Mossman B. Cellular and molecular mechanisma of asbestos- induced fibrosis. Journal of Cellular Physiology 1999; 180(2):158-66.

7. Dement JM, Kuempel ED, Zumwalde RD, Smith RJ, Stayner LT, Loomis D. Development of a fibre size-specific job-exposure matrix for airborne asbestos fibres. Occup Environ Med 2008; 65(9):605-12.

8. Şenyigit A, Babayigit C, Gökirmak M, Topçu F, Asan E, Coşkunsel M, Işik R, Ertem M. Incidence of malignant pleural mesothelioma due to environmental asbestos fiber exposure in the southeast of Turkey. Respiration 2000; 67:610-4. 
9. Dogan M. Environmental pulmonary health problems related to mineral dusts: Examples from central Anatolia, Turkey. Environmental Geology 2002; 41(5):511-79.

10. Berman DW, Crump KS, Chatfield EJ, Davis JM, Jones AD. The sizes, shapes, and mineralogy of asbestos structures that induce lung tumors or mesothelioma in $\mathrm{AF} / \mathrm{HAN}$ rats following inhalation. Risk Anal 1995; 15(2):181-95.

11. Gibbs AR, Wagner JC. Dust Diseases, Environmental Pathology. In: Ün Mc Gee JOOD, Isaacson PG, Wright NA, editors. Oxford Textbook of Pathology, Vol 1, Oxford: Oxford University Press; 1992. p.719-25.

12. Demiroğlu H. Hazards of white asbestos. Lancet 1998; 352:322-3.

13. Yüksel M, Baturel H. Mezotelyoma. In: Yüksel M, Kalaycı NG, editors. Göğüs Cerrahisi (Thoracic surgery). İstanbul,: Nobel Tip Kitabevi; 2001. p.372-3.

14. Şenyiğit A, Dalgıç A, Kavak O. Health effects of asbestos. Dicle Tip Dergisi 2004; 31(4):48-52.

15. Akkurt İ. İnorganik tozlara bağlı akciğer hastalıkları In: Türktaş H, editor. Synopsis of diseases of the chest. Ankara: Güneş Kitabevi Ltd. Şti; 2006:714-43.

16. Kılıçaslan Z. Mesleksel ve çevresel akciğer hastalıkları (Enviromental and occupational lung diseases). In: Arseven O, editor. Akciğer hastalıkları. İstanbul: Nobel Tıp Kitabevleri; 2002. p: 371-9.

17. American Thoracic Society. Diagnosis and initial management of nonmalignant diseases related to asbestos. Am J Respir Crit Care Med. 2004; 170(6):691-715.

18. Miles SE, Sandrini A, Johnson AR, Yates DH. Clinical consequences of asbestos-related diffuse pleural thickening: A review. Journal of Occupational Medicine and Toxicology 2008;3: 20.

19. Gevenois PA, de Maertelaer V, Madani A, Winant C, Sergent G, De Vuyst P. Asbestosis, pleural plaques and diffuse pleural thickening: Three distinct benign responses to asbestos exposure. Eur Respir J. 1998; 11(5):1021-7.

20. Bonomo L, Feragalli B, Sacco R, Merlino B, Storto ML. Malignant pleural disease. Eur J Radiol, 2000; 34(2): 98-118.

21. Demirel S, Zamani AG. Mikronükleus tekniği ve kullanım alanları (Micronucleus assay and areas of usage). Genel Tip Dergisi 2002; 12: 123-7.

22. Gövercin M, Tomatır AG, Evyapan F, Acikbas I, Coşkun G, Akdag B. Elevated micronucleus frequencies in patients with pleural plaque secondary to enviromental exposure to asbestos. Genet Mol Res.2014; 13(1):598-604.

23. Poser I, Rahman Q, Lohani M, Yadav S, Becker HH, Weiss DG, Schiffmann D, Dopp E, Modulation of genotoxic effects in asbestos-exposed primary human mesothelial cells by radical scavengers, metal chelators and a glutathione precursor. Mutat Res 2004; 559(1-2):19-27.

24. Xu A, Smilenov LB, He P, Masumura K, Nohmi T, Yu Z, Hei TK. New insight into intrachromosomal deletions induced by chrysotile in the gpt delta transgenic mutation assay. Environ Health Perspect 2007;115(1):87-92.

25. Donmez-Altuntaş H, Baran M, Oymak FS, Hamurcu Z, Imamoglu N, Ozesmi M, Demirtas H. Investigation of Micronucleus Frequencies in Lymphocytes of Inhabitants Environmentally Exposed to Chrysotile Asbestos. Int J Environ Heal R, 2007; 17 (1): 45-51. 
26. Dragon J, Thompson J, MacPherson M, Shukla A. Differential Susceptibility of Human Pleural and Peritoneal Mesothelial Cells to Asbestos Exposure. J Cell Biochem. 2015;116(8):1540-52.

27. Chew SH, Toyokuni S. Malignant mesothelioma as an oxidative stress-induced cancer: An update. Free Radical Biology and Medicine 2015; 86: 166-78.

28. Vogelstein B, Lane D, Levine AJ. Surfing the p53 network. Nature 2000; 408 (6810): 307-10.

29. Nuorva K, Makitaro R, Huhti E, Kamel D, Vähäkangas K, Bloigu R, Soini Y, Päkkö P. p53 protein accumulation in lung carcinomas of patients exposed to asbestos and tobacco smoke. Am J Respir Crit Care Med 1994; 150:528-33.

30. Mayall FG, Goddard H, Gibbs AR. The frequency of p53 immunostaining in asbestos-associated mesotheliomas and non-asbestos associated mesotheliomas. Histopathology 1993; 22(4): 383-6.

31. Donmez-Altuntas H, Ozturk F, Ilhan-Yilmaz S, Eroz R. Investigation of p53 Tumour Suppressor and Ras Oncogene Mutations in Paraffin Blocks from Patients with Mesothelioma Related to Asbestos and Erionite. Erciyes Medical Journal, 2009; 31(1): 001-008

32. Mishra A, Liu JY, Brody AR, Morris GF. Inhaled asbestos fibres induce p53 expression in the rat lung. Am J Respir Cell Mol Biol 1997; 16(4):479-85.

33. Wade M, Li YC, Wahl GM. MDM2, MDMX and p53 in oncogenesis and cancer therapy. Nat. Rev. Cancer 2013; 13(2):83-96.

34. Pasello GUL, Francesca L, Nannini N, Rea F, Ciminale V, Calabrese F. atoid versus epithelioid malignant pleural mesothelioma Molecular and histological portrait of sarcom (MPM). International Mesothelioma Interest Group (IMIG) Conference Abstract Book, 2014.

35. Mayo LD, Donner DB. A phosphatidylinositol 3-kinase/Akt pathway promotes translocation of Mdm2 from the cytoplasm to the nucleus. Proc Natl Acad Sci USA 2001; 98(20):11598-603.

36. Altomare DA, Vaslet CA, Skele KL, De R, ienzo A, Devarajan K, Jhanwar SC, McClatchey Al, Kane AB, Testa JR. A mouse model recapitulating molecular features of human mesothelioma. Cancer Res 2005; 65(18):8090-5.

37. Zhou S, Liu L, Li H, Eilers G, Kuang Y, Shi S, Yan Z, Li X, Corson JM, Meng F, Zhou H, Sheng Q, Fletcher JA, Ou WB. Multipoint targeting of the PI3K/mTOR pathway in mesothelioma. $B r$. J. Cancer 2014; 110(10):2479-88

38. Cedres S, Montero MA, Martinez P, Martinez A, Rodriguez-Freixinos V, Torrejon D, Gabaldon A, Salcedo M, Ramon y Cajal S, Felip E. Exploratory analysis of activation of PTEN-PI3K pathway and downstream proteins in malignant pleural mesothelioma (MPM). Lung Cancer 2012; 77(1):192-8.

39. Urso L, Calabrese F, Favaretto A, Conte PF, Pasello G. Critical review about MDM2 in cancer: Possible role in malignant mesothelioma and implications for treatment. Critical reviews in Oncology/Hematology. In press 2012; pii: S1040-8428(15)30034-2.

40. Felley-Bosco E, Opitz I, Meerang M. Hedgehog Signaling in Malignant Pleural Mesothelioma. Genes 2015; 6(3):500-11.

41. Broad institute TCGA genome data analysis center: Paradigm pathway analysis of mrnaseq expression and copy number data. Broad institute of MIT and Harvard. Available online: http://gdac.broadinstitute.org/runs/analyses_2014_10_17/reports/cancer/MESO-

TP/Pathway_Paradigm_RNASeq_And_Copy_Number/nozzle.html (accessed on 12 May 2015). 
42. Xia Z, Dickens M, Raingeaud J, Davis RJ, Greenberg ME. Opposing effects of ERK and JNKp38 MAP kinases on apoptosis. Science 1995; 270(5240):1326-31.

43. Kamp DW, Weitzman SA. The molecular basis of asbestos induced lung injury. Thorax 1999; 54(7):638-52.

44. Zanella CL, Posada J, Tritton TR, Mossman BT. Asbestos causes stimulation of the extracellular signal-regulated kinase 1 mitogen-activated protein kinase cascade after phosphorylation of the epidermal growth factor receptor. Cancer Res 1996; 56(23):5334-8.

45. Wang H, Gillis A, Zhao C, Lee E, Wu J, Zhang F, Ye F, Zhang D.Y. Crocidolite asbestos-induced signal pathway dysregulation in mesothelial cells. Mutation Research 2011; 723(2):171-6.

46. Fujii M, Toyoda D, Nakanishi H, Yatabe Y, Sato A, Matsudaira Y, Ito H, Murakami H, Kondo Y, Kondo E, Hida T, Tsujimura T, Osada H, Sekido Y. TGF-beta synergizes with defects in the Hippo pathway to stimulate human malignant mesothelioma growth. J Exp Med 2012 ;209(3):479-94.

47. Jiang L, Yamashita Y, Chew SH, Akatsuka S, Ukai S, Wang S, Nagai H, Okazaki Y, Takahashi $\mathrm{T}$, Toyokuni S. Connective tissue growth factor and beta-catenin constitute an autocrine loop for activation in rat sarcomatoid mesothelioma. J Pathol 2014; 233(4):402-14.

48. Huang SXL, Jaurand M-C, Kamp DW, Whysner J, Hei TK. Role of mutagenicity in asbestos fiber-induced carcinogenicity and other diseases. J. Toxicol. Environ. Health. 2011; 14:179-245.

49. Kamp DW, Graceffa P, Pryor WA, Weitzman SA. The role of free radicals in asbestos-induced diseases. Free Radic. Biol. Med. 1992; 12:293-315.

50. Liu G, Beri R, Mueller A, Kamp DW. Molecular mechanisms of asbestos-induced lung epithelial cell apoptosis. Chem. Biol. Interact. 2010; 188:309-18.

51. Hiraku Y, Kawanishi S, Ichinose T, Murata M. The role of iNOS-mediated DNA damage in infection- and asbestos-induced carcinogenesis. Ann. N.Y. Acad. Sci. 2010; 1203:15-22.

52. Gang L, Cheresh P, Kamp DW. Molecular Basis of Asbestos-Induced Lung Disease. Annu Rev Pathol 2013; 8: 161-87.

53. Fattman CL, Tan RJ, Tobolewski JM, Oury TD. Increased sensitivity to asbestos-induced lung injury in mice lacking extracellular superoxide dismutase. Free Radic Biol Med_2006;40(4):6017.

54. Dostert C, Petrilli V, Van Bruggen R, Steele C, Mossman BT, Tschopp T. Innate immune activation through Nalp3 inflammasome sensing of asbestos and silica. Science 2008; 320:674677.

55. Bartel DP. MicroRNAs: genomics, biogenesis, mechanism, and function. Cell 2004; 116(2):28197.

56. Calin GA, Sevignani C, Dumitru CD, Hyslop T, Noch E, Yendamuri S, Shimizu M, Rattan S, Bullrich F, Negrini M, Croce CM. Human microRNA genes are frequently located at fragile sites and genomic regions involved in cancers. Proceedings of the National Academy of Sciences of the United States of America 2004;101(9):2999-3004.

57. Wang D, Qiu C, Zhang H, Wang J, Cui Q, Yin Y. Human MicroRNA oncogenes and tumor suppressors show significantly different biological patterns: from functions to targets. PLoS ONE 2010; 5(9):e13067. 
58. Volinia S, Calin GA, Liu CG, Ambs S, Cimmino A, Petrocca F, Visone R, Iorio M, Roldo C, Ferracin M, Prueitt RL, Yanaihara N, Lanza G, Scarpa A, Vecchione A, Negrini M, Harris CC, Croce CM. A microRNA expression signature of human solid tumors defines cancer gene targets. Proceedings of the National Academy of Sciences of the United States of America 2006; 103(7):2257-61.

59. Yanaihara N, Caplen N, Bowman E, Seike M, Kumamoto K, Yi M, Stephens RM, Okamoto A, Yokota J, Tanaka T, Calin GA, Liu C, Croce CM, Harris CC. Unique microRNA molecular profiles in lung cancer diagnosis and prognosis. Cancer Cell 2006; 9(3):189-98.

60. Yu SL, Chen HY, Chang GC, Chen CY, Chen HW, Singh S, Cheng CL, Yu CJ, Lee YC, Chen HS, Su TJ, Chiang CC, Li HN, Hong QS, Su HY, Chen CC, Chen WL, Liu CC, Chan WK, Chen WJ, Li KC, Chen JJW, Yang PC. MicroRNA signature predicts survival and relapse in lung cancer. Cancer Cell 2008; 13(1):48-57.

61. Duncavage E, Goodgame B, Sezhiyan A, Govindan R, Pfeifer J. Use of MicroRNA expression levels to predict outcomes in resected stage in non-small cell lung cancer. Journal of Thoracic Oncology 2015; 5(11):1755-1763.

62. He J, Zhang JF, Yi C, Lv Q, Xie WD, Li JN, Wan G, Cui K, Kung H, Yang J, Yang BB, Zhang Y. miRNA-mediated functional changes through co-regulating function related genes. PLoS ONE 2010; 5(10):e13558.

63. Guled M, Lahti L, Lindholm PM, Salmenkivi K, Bagwan I, Nicholson AG, Knuutila S. CDKN2A, NF2, and JUN are dysregulated among other genes by miRNAs in malignant mesothelioma — a miRNA microarray analysis. Genes Chromosomes Cancer 2009; 48(7):615-23.

64. Santarelli L, Strafella E, Staffolani S, Amati M, Emanuelli M, Sartini D, Pozzi V, Carbonari D, Bracci M, Pignotti E, Mazzanti P, Sabbatini A, Ranaldi R, Gasparini S, Neuzil J, Tomasetti M. Association of MiR-126 with soluble mesothelin-related peptides, a marker for malignant mesothelioma. PLoS One 2011; 6(4):e18232.

65. Benjamin H, Lebanony D, Rosenwald S, Cohen L, Gibori H, Barabash N, Ashkenazi K, Goren E, Meiri E, Morgenstern S, Perelman M, Barshack I, Goren Y, Edmonston TB, Chajut A, Aharonov R, Bentwich Z, Rosenfeld N, Cohen D. A diagnostic assay based on microRNA expression accurately identifies malignant pleural mesothelioma. J Mol Diagn 2010; 12(6):7719.

66. Gee GV, Koestler DC, Christensen BC, Sugarbaker DJ, Ugolini D, Ivaldi GP, Resnick MB, Houseman EA, Kelsey KT, Marsit CJ. Downregulated microRNAs in the differential diagnosis of malignant pleural mesothelioma. Int J Cancer 2010; 127(12):2859-69.

67. Busacca S, Germano S, De Cecco L, Rinaldi M, Comoglio F, Favero F, Murer B, Mutti L, Pierotti M, Gaudino G. MicroRNA signature of malignant mesothelioma with potential diagnostic and prognostic implications. Am J Respir Cell Mol Biol 2010; 42(3): 312-9.

68. Balatti V, Maniero S, Ferracin M, Veronese A, Negrini M, Ferrocci G, Martini F, Tognon MG. MicroRNAs dysregulation in human malignant pleural mesothelioma. J Thorac Oncol 2011; 6(5):844-51.

69. Pass HI, Goparaju C, Ivanov S, Donington J, Carbone M, Hoshen M, Cohen D, Chajut A, Rosenwald S, Dan H, Benjamin S, Aharonov R. hsa-miR-29c* is linked to the prognosis of malignant pleural mesothelioma. Cancer Res 2010; 70(5):1916-24.

70. Kirschner MB, Cheng YY, Badrian B, Kao SC, Creaney J, Edelman JJ, Armstrong NJ, Vallely MP, Musk AW, Robinson BW, McCaughan BC, Klebe S, Mutsaers SE, van Zandwijk N, Reid G. Increased circulating miR-625-3p: a potential biomarker for patients with malignant pleural mesothelioma. J Thorac Oncol 2012; 7(7):1184-91. 
71. Ivanov SV, Goparaju CM, Lopez P, Zavadil J, Toren-Haritan G, Rosenwald S, Hoshen M, Chajut A, Cohen D, Pass HI. Pro-tumorigenic effects of miR-31 loss in mesothelioma. The Journal of Biological Chemistry 2010; 285 (30):22809-17.

72. Weber DG, Johnen G, Bryk O, Jöckel KH, Brüning T. Identification of miRNA-103 in the cellular fraction of human peripheral blood as a potential biomarker for malignant mesothelioma - a pilot study. PLoS ONE 2012; 7(1):e30221.

73. Ak G, Tomaszek SC, Kosari F, Metintas M, Jett JR, Metintas S, Yildirim H, Dundar E, Dong J, Aubry MC, Wigle DA, Thomas CF Jr. MicroRNA and mRNA features of malignant pleural mesothelioma and benign asbestos related pleural effusion. Biomed Res Int. 2015; 2015:635748.

74. Mozzoni P, Ampollini L, Goldoni M, Alinovi R, Tiseo M, Gnetti L, Carbognani P, Rusca M, Mutti A, Percesepe A, Corradi M. MicroRNA Expression in Malignant Pleural Mesothelioma and Asbestosis: A Pilot Study. Dis Markers. 2017;2017:9645940

75. Emanuela Felley-Bosco, Hubert Rehrauer. Non-Coding Transcript Heterogeneity in Mesothelioma: Insights from Asbestos-Exposed Mice. Int. J. Mol. Sci. 2018;19:1163 